\title{
Larvicidal effects of supercritical extract of Melia azedarach and Bacillus thuringiensis var. israelensis product on late instar of Aedes aegypti (Diptera: Culicidae)
}

\author{
Efecto larvicida de extracto supercrítico de Melia azedarach y Bacillus thuringiensis var. israelensis \\ sobre larvas de Aedes aegypti (Diptera: Culicidae)

\begin{abstract}
MARIA ASSUNTA BUSATO ${ }^{1,2}$, JUNIR ANTONIO LUTINSKI ${ }^{1,3}$, DENILSO HERMES ${ }^{1,4}$, JACIR DAL MAGRO $^{1,5}$, CRISTIANO MOSCHEN BORDIGNON ${ }^{1,6}$, ALINE BOHN ${ }^{1,7}$ and DANIEL ALBENY SIMÕES ${ }^{1,8}$
\end{abstract}

\begin{abstract}
The intense use of synthetic products for the control of Aedes aegypti has led to the development of resistance and imposes health risks to other flora and fauna. This study assessed the larvicidal potential of Melia azedarach (Meliaceae) fruit extract obtained by the supercritical carbon dioxide extraction method and Bacillus thuringiensis var. israelensis (Bti) on second and third instar A. aegypti larvae under laboratory conditions. The assays were performed in disposable cups containing $100250,500,750,1,000$ and 2,000 $\mu \mathrm{g} / \mathrm{ml}$ extracts of $M$. azedarach, and $0.0005,0.001$, $0.0015,0.002$, and $0.0025 \mathrm{~g} / \mathrm{L}$ of VectoBac $\mathrm{WG}^{\circledR}$; the controls contained only water. Ten active larvae were added to each well, and the number of living larvae was counted each day for $72 \mathrm{~h}$. Treatment efficiency was calculated using Abbott's equation. Insecticidal efficiency increased with $M$. azedarach extract concentration, with significant effects in the 1,000 and $2,000 \mu \mathrm{g} / \mathrm{mL}$ concentration range. Bti efficiency was $100 \%$ in the first $24 \mathrm{~h}$. The results indicate the possibility of $A$. aegypti population control using supercritical extracts of $M$. azedarach.
\end{abstract}

Key words: Natural products, plant extracts, dengue, mosquito control.

Resumen: La utilización de productos sintéticos en el control de mosquitos Aedes aegypti ha inducido en sus poblaciones la resistencia e impone riesgos a la fauna y flora. En este estudio fueron evaluados el efecto del extracto del fruto de Melia azedarach (Meliaceae) obtenido a través del método de extracción con dióxido de carbono supercrítico y el potencial larvicida del Bacillus thuringiensis var. israelensis (Bti) sobre los inmaduros de A. aegypti en condiciones de laboratorio. Los ensayos fueron realizados en vasos desechables con 100, 250, 500, 750, 1.000 and $2.000 \mu \mathrm{g} / \mathrm{ml} \mathrm{de}$ concentración de extracto de $M$. azedarach, y $0,0005,0,001,0,0015,0,002$ y $0,0025 \mathrm{~g} / \mathrm{L}$ de VectoBac WG ${ }^{\circledR}$, y como controles, agua. Para cada vaso fueron adicionadas 10 larvas activas. Los resultados fueron comparados considerando el número de larvas vivas contadas a diario durante $72 \mathrm{~h}$. La eficiencia de los tratamientos probados fue calculada por la ecuación de Abbott. El extracto supercrítico de M. azedarach presentó acción positiva para las concentraciones de 1.000 y $2.000 \mu \mathrm{g} / \mathrm{mL}$. Para el Bti la eficiencia fue del $100 \%$ en las primeras $24 \mathrm{~h}$. Los resultados indican la posibilidad del control poblacional del $A$. aegypti a partir del extracto supercrítico de $M$. azedarach.

Palabras clave: Productos biológicos, extractos vegetales, dengue, control de mosquitos.

\section{Introduction}

The mosquito Aedes aegypti (Linnaeus, 1762) is a vector of dengue, Chikungunya fever, Zika virus, and urban yellow fever. Mosquitoes undergo complete metamorphosis (i.e. they are holometabolous), passing through egg, larval (4 stages), pupal, and adult stages (Araújo et al. 2015; Soaresda-Silva et al. 2015). A. aegypti belongs to family Culicidae, which has wide global distribution in tropical and subtropical areas, with geographic range being limited by altitude and low temperatures only (Funasa 2001). The adaptation of this organism to man-made environments is likely to have caused this synanthropic behavior (Natal 2002; Costa et al. 2012). Population growth and spread of this organism has been exacerbated by human migration from rural areas to urban centers, as well as the lack of basic sanitation (Tauil 2001; Zara et al. 2016).
Systematic control of $A$. aegypti by government agencies in Brazil began in the mid-nineteenth century, due to a series of national epidemics that led to the death of thousands of people (Funasa 2001). The main tool still used today for control of adult mosquito populations is ultra-low volume pesticide application (ULV) (Paixão 2007). Pyriproxyfen larvicide (Sumilarv ${ }^{\circledR}$ ) is used to reduce larval populations, which is involves the ether group chemical pyridyloxypropyl, a juvenile hormone analog (WHO 2007; Santa Catarina 2012). Biological control using natural enemies is also employed (Panplona et al. 2009; Albeny-Simoes et al. 2011, 2012) as well as use of biolarvicides based on Bacillus thuringiensis var. israelensis (Bti) (Arcy et al. 2014). The use of chemicals has not been effective in controlling vector populations or the incidence of dengue (Beserra et al. 2007), and this results in either immediate damage or future risks to the environment and human health (Gomes

\footnotetext{
${ }^{1}$ Universidade Comunitária da Região de Chapecó, Av. Attílio Fontana, 591E, Chapecó, SC, Brazil. ${ }^{2}$ Ph. D. in Biology. Pos-Graduate Program in Health Sciences, Universidade Comunitária da Região de Chapecó, Chapecó, SC, Brazil, assunta@unochapeco.edu.br. ${ }^{3}$ Ph. D. in Biology. Pos-Graduate Program in Health Sciences, Universidade Comunitária da Região de Chapecó, Chapecó, SC, Brazil, junir@unochapeco.edu.br. ${ }^{4}$ Graduate in Biological Sciences, Universidade Comunitária da Região de Chapecó, Chapecó, SC, Brazil, denilso@unochapeco.edu.br. ${ }^{5}$ Ph. D. in Chemistry, Pos-Graduate Program in Environmental Sciences, Universidade Comunitária da Região de Chapecó, Chapecó, SC, Brazil, jacir@unochapeco.edu.br. ${ }^{6}$ Graduate in Biological Sciences, Universidade Comunitária da Região de Chapecó, Chapecó, SC, Brazil, cristianombn@unochapeco.edu.br. ${ }^{7}$ Graduate in Chemical Engineering, alinebohn@unochapeco.edu.br. ${ }^{8}$ Ph. D. in Biology. Pos-Graduate Program in Environmental Sciences, Universidade Comunitária da Região de Chapecó, Chapecó, SC, Brazil, danielalbeny@unochapeco.edu.br. Corresponding author: Maria Assunta Busato. Ph. D. in Biology. Pos-Graduate Program in Health Sciences, Universidade Comunitária da Região de Chapecó, Av. Attílio Fontana, 591E, Chapecó, SC, Brazil, assunta@unochapeco.edu.br.
} 
2014). Although past attempts were made to artificially select for Bti resistance in the laboratory (Goldman at al. 1986), these methods have thus far been ineffective in A. aegypti (Boyce et al. 2013). In addition, some gaps in literature exist regarding the product concentrations used for control of $A$. aegypti. The manufacturer of AM65-52 strain VectoBac $\AA$ $\mathrm{WG}$, recommends a concentration of $0.002 \mathrm{~g} / \mathrm{L}$ for larval control. The Bti action efficiency under field conditions can be different from totally controlled laboratory experiments, because it can be affected by several environmental factors such as, organic matter and pollutants input, water quality and sun light exposure (Mulla et al. 1990; Pusztai et al. 1991).

The use of plant-based products in pest control has been widely studied (Valladares et al. 1997; Krinski et al. 2014; Busato et al. 2015), mainly due to the high biodegradability, decreased toxicity for non-target species, and the potential of those substances to serve as alternatives to commercially available synthetic compounds (Ghosh et al. 2012). Melia azedarach L., 1753 is fast-growing plant with worldwide distribution in the Meliaceae family, popularly known as cinnamon, lilac or santa-barbaric lily (Kingsbury 1964). $M$. azedarach has demonstrated insecticidal activity, making it a promising avenue for biological control of mosquito larvae, and has been proposed as a possible larvicide, especially for mosquitoes in the genus Aedes (Rossi et al. 2007; Coria et al. 2008; Busato et al. 2015). Extracts containing active ingredients are produced from plant material via solid-liquid extraction with organic solvents such as ethanol, methanol, ethyl acetate, chloroform, or hexane (Yunes and Calixto 2001). After the macerated plant material is soaked for some time in the solvent, the solution is then evaporated by distillation to obtain a dry extract through high temperature. The main drawback of this technology is the possibility of decomposition of the thermolabile active principles, as well as contamination of the extract by the solvent and impurities contained therein.

Among the technologies used to obtain the plant extracts, supercritical fluid extraction has advantages over conventional extraction methods, including greater extract purity due to the absence of organic solvents, less waste, and lower processing temperatures. Among the solvents used in a supercritical state, carbon dioxide is generally the most popular (Mendiola et al. 2007). This is an interesting solvent for natural products and foods, as in the process can be operated at low temperatures, which allow the extraction of thermolabile compounds. Another advantage of $\mathrm{CO}_{2}$ is its gaseous state at room temperature and pressure, which makes it a very simple recovery and provides free analyst solvents.

This study has two objectives: i) to evaluate the efficiency of supercritical carbon dioxide $\left(\mathrm{SC}-\mathrm{CO}_{2}\right)$ extraction of $M$. azedarach on the survival of $A$. aegypti larvae and ii) to evaluate the larvicidal potential of Bti when used in lower concentrations than those recommended by the manufacturer.

\section{Materials and methods}

Egg collection. A. aegypti eggs were collected between November 2014 and March 2015 in Chapecó, Santa Catarina State, Brazil $\left(27^{\circ} 05^{\prime} 48^{\prime \prime S} 52^{\circ} 37^{\prime} 70^{\prime \prime} \mathrm{W}\right)$, in areas with high occurrence of this species (Santa Catarina 2012).
We installed 16 ovitraps constructed with black plastic 1 L capacity bottles. Three Eucatex ${ }^{\circledR}$ wooden pallets were placed into each trap and replaced each four to six days. The collected pallets were kept in the laboratory at room temperature, and eggs were counted under electronically stereomicroscope, $40 \mathrm{X}$.

Preparation of plant extracts. Ripe $M$. azedarach fruit were collected in February 2015 in the municipality of Tigrinhos,

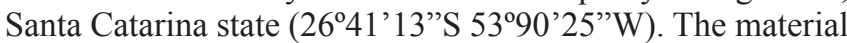
was stored at $-20^{\circ} \mathrm{C}$ until extract preparation. The seeds were ground to about $1 \mathrm{~mm}$ particle size and placed in an extractor. Supercritical fruit extract was obtained as described by Scapinello et al. (2014a, 2014b), which suggests a temperature of $40{ }^{\circ} \mathrm{C}$ and 250 bar pressure with 90 minutes of extraction. The resulting extract was dissolved in $0.5 \mathrm{ml}$ of Tween $80 \AA$ per $100 \mathrm{ml}$ of distilled water, diluted to the following concentrations: $250 \mu \mathrm{g} / \mathrm{ml}, 500 \mu \mathrm{g} / \mathrm{ml}, 750 \mu \mathrm{g} / \mathrm{ml}, 1,000 \mu \mathrm{g} /$ $\mathrm{ml}$, and $2,000 \mu \mathrm{g} / \mathrm{ml}$. Extracts were maintained at $4{ }^{\circ} \mathrm{C}$ until use. These $M$. azedarach extract concentrations were used to evaluate each concentration effectiveness on $A$. aegypti larvae mortality. Plant extract concentrations were stablished after a previous pilot test $(0.0005 \mathrm{~g} / \mathrm{L})$ that indicated the positive or negative activity trend of each concentration.

Bti preparation. Vectobac $\mathrm{WG}^{\circledR}$ Bacillus thuringiensis var. israelis (wettable powder) was obtained from an agricultural product distributor. The product was weighed on an analytical balance and solubilized in ultrapure water at concentrations of $0.0005 \mathrm{~g} / \mathrm{L}, 0.001 \mathrm{~g} / \mathrm{L}, 0.0015 \mathrm{~g} / \mathrm{L}, 0.002 \mathrm{~g} / \mathrm{L}$, and 0.0025 $\mathrm{g} / \mathrm{L}$. These concentrations were chosen based on dilutions of the recommended concentration by the manufacturer, which kills the $100 \%$ of the exposed larvae.

Bioassays. These were performed in a climate controlled room in the laboratory at $28^{\circ} \mathrm{C}$ to $30{ }^{\circ} \mathrm{C}$ with a $12: 12 \mathrm{~L}: \mathrm{D}$ photoperiod. Pallets with eggs were placed in trays with untreated, artesian well water and supplied with aquarium fish food (Alcon Basic Complex ${ }^{\circledR}$ MEP 200) for hatching, and larvae were maintained with ample food until reaching second and third instar (L2 and L3).

Ten L2/L3 larvae were then transferred to $180 \mathrm{ml}$ plastic cups containing $100 \mathrm{ml}$ of either experimental solution (water + Bti or plant extract), or control solution (water only). The numbers of surviving larvae were registered at 24, 48 and 72 hours. Each combination of concentration and compound (Bti or M. azedarach extract) was replicated three times.

Statistical analysis. Mean numbers of live larvae were analyzed by ANOVA with means grouped using Duncan's test with $5 \%$ error probability. Data were $\log (\mathrm{x}+1)$ transformed prior to analysis. Treatment efficiency was calculated using Abbott's formula (Abbott 1925).

The mean number of live larvae was analyzed by oneway ANOVA. The factor was treatments at 72 hours exposure time. Treatment factor was composed by six levels, considering $M$. azedarach concentrations and the control. Statistical difference between each pair of treatments means were analyzed by Tukey post-hoc test $(\mathrm{P}<0.05)$. To adjust error distribution, the data were $\log (\mathrm{x}+1)$ transformed prior to analysis. Treatment efficiency was calculated using Abbott's formula (Abbott 1925). 
Table 1. Analysis of variance comparing larvicidal effects of different concentrations of $M$. azedarach supercritical extract against $A$. aegypti larvae after 72 hours of exposure. One-way ANOVA, factor: treatments. Levels: $M$. azedarach concentrations and the control. Tukey post-hoc test $(\mathrm{P}<0.05)$.

\begin{tabular}{lcccc}
\hline \multicolumn{1}{c}{ Variation } & DF & SM & F & P \\
\hline Between groups & 5 & 38.3 & 76.6 & $<0.0001$ \\
Within groups & 12 & 0.5 & & \\
Total & 17 & & & \\
\hline
\end{tabular}

$\mathrm{DF}=$ Degrees of freedom; $\mathrm{SM}=$ Square means.

\section{Results}

The $M$. azedarach supercritical extract showed significant (F $=76.6 ; \mathrm{P}<0.0001)$ larvicidal action, with $100 \%$ efficiency after 72 hours of larval exposure at 2,000 $\mu \mathrm{g} / \mathrm{ml}$ (Table 1). The 250, 500 and $750 \mathrm{mg} / \mathrm{mL}$ concentrations did not differ significantly in efficiency from control (Fig. 1). The 1,000 $\mu \mathrm{g} /$ $\mathrm{mL}$ had $33.4 \%$ of larval mortality, with results significantly different from all other treatments (Table 2, Fig. 1). The high efficiency was only reached at the highest concentration $(2,000 \mu \mathrm{g} / \mathrm{mL})(100 \%)$ (Table 2$)$ after 72 hours of exposure. The Bti was $100 \%$ efficient in all concentrations and at all exposure periods, larval mortality effectively until $24 \mathrm{~h}$ exposure time in laboratory conditions.

After exposure period of 72 hours, were observed significant differences between the supercritical extracts of Melia azedarach (M.a.) at different concentrations above the number of $A$. aegypti larvae alive (Fig. 1).

\section{Discussion}

M. azedarach supercritical extract showed larvicidal action. The two smaller concentrations reached $10 \%$ efficiency. At

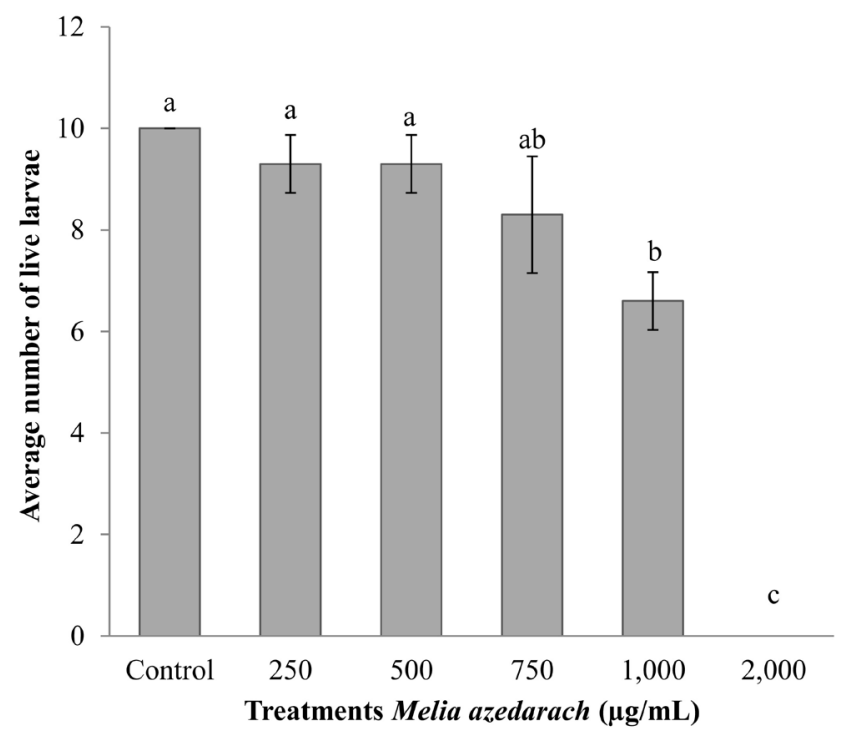

Figure 1. Larvicidal efficiencies of Melia azedarach supercritical extracts at different concentrations. Vertical bars indicate standard error of the mean number of $A$. aegypti larvae alive after exposure period of 72 hours. Different letters indicate significant differences between treatment groups (Tukey post-hoc test).
Table 2. Average number of surviving A. aegypti larvae after different exposure periods to larvicides and percent efficiency after 72 hours exposure.

\begin{tabular}{|c|c|c|c|c|}
\hline \multirow{2}{*}{ Treatment } & \multicolumn{3}{|c|}{ Mean \# surviving larvae } & \multirow{2}{*}{$\begin{array}{c}\text { Efficiency } \\
(\%)\end{array}$} \\
\hline & $24 \mathrm{~h}$ & $48 \mathrm{~h}$ & $72 \mathrm{~h}$ & \\
\hline Control & 10 & 10 & 10 & 0.0 \\
\hline \multicolumn{5}{|c|}{ Melia azedarach $\mathrm{SC}-\mathrm{CO}_{2}$} \\
\hline $250 \mu \mathrm{g} / \mathrm{mL}$ & 9.6 & 9.3 & 9 & 10.0 \\
\hline $500 \mu \mathrm{g} / \mathrm{mL}$ & 10 & 9.3 & 9 & 10.0 \\
\hline $750 \mu \mathrm{g} / \mathrm{mL}$ & 10 & 9.6 & 8.3 & 17.2 \\
\hline $1,000 \mu \mathrm{g} / \mathrm{mL}$ & 8.9 & 8.3 & 6.5 & 34.9 \\
\hline $2,000 \mu \mathrm{g} / \mathrm{mL}$ & 4.9 & 0.3 & 0 & 100.0 \\
\hline
\end{tabular}

SC: Supercritical extract.

the two highest concentrations, 1,000 and 2,000 $\mu \mathrm{g} / \mathrm{mL}$, larval mortality was observed in 24 hours. However, the average number of live larvae decreased as period of exposure increased in the two highest concentrations $(1,000$ and $2,000 \mu \mathrm{g} / \mathrm{ml})$, with $33.4 \%$ and $A$. aegypti $100 \%$ mortality, respectively. The susceptibility of larvae to this extract may be due to the insecticidal effects of $M$. azedarach compounds such as azadirachtin (Carpinella et al. 2003). Insecticidal action may also be attributed to other associated compounds, particularly terpenes, sterols and coumarins obtained from M. azedarach during the carbon dioxide extraction (Scapinello et al. 2014b). The Meliaceae family contains plants with the highest known seed terpenoid concentration in the Chapecó region, and these compounds have known larvicidal action (Rossi et al. 2007; Freitas 2008). This result is important and opens a new study window to use $M$. azedarach on $A$. aegypti control.

Three of the Bti concentrations used (0.0005, 0.001 and $0.0015 \mathrm{~g} / \mathrm{L})$, are lower than the manufacturer's recommendation (i.e., $0.002 \mathrm{~g} / \mathrm{L}$ for AM65-52 strain VectoBac ${ }^{\circledR}$ WG) was $100 \%$ efficient in all concentrations and at all exposure periods, larval mortality effectively until $24 \mathrm{~h}$ exposure time in laboratory conditions.

Bti is currently the most commonly used bacterium for insecticidal purposes (Silva et al. 2014) and is highly effective in controlling A. aegypti larvae (Lima et al. 2005; Boyce 2013), without provoking toxic effects in humans, either by ingestion or skin contact (WHO 2004). Moreover, it does not show adverse effects to others animal species and is considered non-pathogenic and non-toxic (WHO 1999). Bti has been used in vector control programs for more than 20 years, and there have not so far been records of resistance (Braga and Valle 2007; Boyce 2013).

In this study, a dilution of $75 \%$ of the concentration recommended by the manufacturer was enough to kill all larvae exposed to the product at issue. Generally, the recommended concentrations of a commercial larvicide are several times higher than the lethal concentration obtained under laboratory conditions because in the field there are other factors that may affect the effectiveness of the active compound, such as organic loads, pollution, water temperature and solar light (Mulla et al. 1990; Pusztai et al. 1991; Armengol et al. 2006). Nevertheless, other products are being studied for controlling this vector, such as, for example, vegetal extracts, such as $M$. azedarach, which is analyzed in this study. 


\section{Conclusion}

The results herein suggest alternative methods for $A$. aegypti population control. The extraction method for $M$. azedarach compounds can be a determining factor to maximize the efficiency of this plant extract as larvicide. In relation to Bti, those results suggest the possibility of this being considered as a powerful tool to be used by the municipality dengue control program.

\section{Acknowledgements}

The authors thank National Counsel of Technological and Scientific Development (CNPq) for financial support.

\section{Literature cited}

ABBOTT, W. S. A. 1925. Method of computing the effectiveness of an insecticide. Journal of Economic Entomology 18: 265-267.

ALBENY-SIMÕES, D.; MARTINS, G.; ANDRADE, M.; KRÜGER R.; VILELA, E. 2011. Aedes aegypti survival in the presence of Toxorhynchites violaceus (Diptera: Culicidae) fourth instar larvae. Zoologia 28 (4): 538-540.

ALBENY-SIMÕES, D.; ROSA, C.; KRÜGER, R. F.; ATAIDE, L. M. S.; VILELA, E. F. 2012. Variation of Aedes aegypti larvae predation by Toxorhynchites violaceus larvae (Diptera: Culicidae) according to habitats dimensions. BioAssay 7 (4): $1-5$.

ARAÚJO, H. R. C.; CARVALHO, D. O.; IOSHINO, R. S.; COSTADA-SILVA, A. L.; CAPURRO, M. L. 2015. Aedes aegypti Control strategies in Brazil: incorporation of new technologies to overcome the persistence of dengue epidemics. Insects 6 (2): 576-594.

ARCY, A. R.; SILVA, M.; CUNHA, T. L. 2014. Testes ecotoxicológicos de diferentes formulações do bioinseticida produzido na UNIVILLE submetidas ao teste de prateleira. Engenharia Sanitária e Ambiental 19 (4): 435-440.

ARMENGOL, G.; HERNANDEZ, J.; VELEZ, J. G.; ORDUZ, S. 2006. Long-lasting effects of a Bacillus thuringiensis serovar israelensis experimental tablet formulation for Aedes aegypti (Diptera: Culicidae) control. Journal of Economic Entomology 99: 1590-1595.

BESERRA, E. B.; FERNANDES, C. R. M.; QUEIROGA, M. F. C.; CASTRO-JUNIOR, F. P. 2007. Resistência de populações de Aedes aegypti (L.) (Diptera: Culicidae) ao organofosforado temefós na Paraíba. Neotropical Entomology 36 (2): 303-307.

BOYCE, R.; LENHART, A.; KROEGER, A.; VELAYUDHAN, R.; ROBERTS, B.; HORSTICK, O. 2013. Bacillus thuringiensis israelensis (Bti) for the control of dengue vectors: systematic literature review. Tropical Medicine and International Health 18: 564-577.

BRAGA, I. A.; VALLE, D. 2007. Aedes aegypti: inseticidas, mecanismos de ação e resistência. Epidemiologia e Serviços de Saúde 16 (4): 279-293.

BUSATO, M. A.; VITORELlO, J.; LUTINSKI, J. A.; DAL MAGRO, J.; SCAPINELLO, J. 2015. Potencial larvicida de Melia azedarach L. e Ilex paraguariensis A. St.-Hil. no controle de Aedes aegypti (Linnaeus, 1762) (Diptera: Culicidae). Ciência e Natura 37 (2): 277-282.

CARPINELLA, M. C.; DEFAGO, M. T.; VALLADARES, G.; PALACIOS, S. M. 2003. Antifeedant and insecticide properties of a limnoid from Melia azedarach (Meliaceae) with potencial use for pest management. Journal of Agricultural and Food Chemistry 15 (51): 369-374.

CORIA, C.; ALMIRON, W.; VALLADARES, G.; CARPINELLA, C.; LUDUEÑA, F.; DEFAGO, M.; PALACIOS, S. 2008. Larvicide and oviposition deterrent effects of fruit and leaf extracts from Melia azedarach L. on Aedes aegypti (L.) (Diptera: Culicidae). Bioresource Technology 99: 3066-3070.

COSTA, F.; FATTORE, G.; ABRIL, M. 2012. Diversity of containers and buildings infested with Aedes aegypti in Puerto Iguazú, Argentina. Cadernos de Saúde Pública, Rio de Janeiro 28 (9): 1802-1806.

FREITAS, S. R. Q. 2008. Bioatividade de extratos aquosos de Eucalyptus sp. L'Hér. (Myrtaceae) e Meliaazedarach L. (Meliaceae) sobre Musca domestica L. (Diptera, Muscidae). 80f. M. Sc. Thesis, Universidade Federal de Pelotas, Brazil.

FUNASA, Fundação Nacional de Saúde. 2001. Instruções para pessoal de combate ao vetor, Manual de Normas Técnicas. Brasília.

GHOSH, A.; CHOWDHURY, N.; CHANDRA, G. 2012. Plant extracts as potential mosquito larvicides. Indian Journal of Medical Research 135 (5): 581-598.

GOLDMAN, I. F.; JONATHAN, A.; CARLTON, B. C. 1986. Selection for resistance to Bacillus thuringiensis subspecies israelensis in field and laboratory populations of the mosquito Aedes aegypti. Journal of Invertebrate Pathology 41 (3): 317324.

GOMES, W. 2014. Uso de inseticida (organofosforado) no combate à dengue e os possíveis danos à saúde pública na área urbana de Foz do Iguaçu-Pr. 42f. Monografia de Pós-Graduação Gestão Ambiental em Municípios - Pólo UAB do Município de Foz do Iguaçu.

KINGSBURY, J. M. 1964. Poisonous plants of the United States and Canada. Prentice-Hall Inc., Englewood Cliffs 206-208.

KRINSKI, D.; MASSAROLI, A.; MACHADO, M. 2014. Potencial inseticida de plantas da família Annonaceae. Revista Brasileira de Fruticultura 36 (1): 225-242.

LIMA, J. B. P.; MELO, N. V.; VALLE, D. 2005. Residual effect of two Bacillus thuringiensis var. israelensis products assayed against Aedes aegypti (Diptera: Culicidae) inlaboratory and outdoors at Rio de Janeiro, Brazil. Revista do Instituto de Medicina Tropical 47 (3): 125-130.

MENDIOLA, J. A.; HERRERO, M.; CIFUENTES, A.; IBÃNEZ, E. 2007. Use of compressed fluids for sample preparation: food applications. Journal of Chromatography A 1152 (1-2): 234246.

MULLA, M. S.; DARWAZEH, H. A.; ZGOMBA, M. 1990. Effect of some environmental factors on the efficacy of Bacillus sphaericus 2362 and Bacillus thuringiensis H-14 against mosquitoes. Bulletin of the Society for Vector Ecology 15 (2): 166-175.

NATAL, D. 2002. Bioecologia do Aedes aegypti. Biológico 64 (2): 205-207.

PAIXÃO, K. S. 2007. Avaliação do controle químico de adultos de Aedes (Stegomyia) aegypti (Linnaeus, 1762) (Diptera: Culicidae) de Fortaleza por meio de métodos convencionais e das armadilhas BG-Sentinel ${ }^{\circledR}$ e MosquiTRAP ${ }^{\circledR}$. 118f. Universidade Federal de Minas Gerais Instituto de Ciência Biológicas, Belo Horizonte, MG, Brasil.

PANPLONA, L. G. C.; ALENCAR, C. H.; LIMA, J. W. O.; HEUKELBACH, J. M. 2009. Reduced oviposition of Aedes aegypti gravid females in domestic containers with predatory fish. Tropical Medicine and International Health 14 (11): 13471350 .

PUSZTAI, M.; FAST, P.; GRINGORTEN, L.; KAPLAN, H.; LESSARD, T.; CAREY, P. R. 1991. The mechanism of sunlightmediated inactivation of Bacillus thuringiensis crystals. Biochemical Journal 1 (273): 43-47.

ROSSI, J. C. N.; PROPHIRO, J. S.; MENDES, A. M.; KANIS, L. A.; SILVA, O. S. 2007. Efeito larvicida de extratos etanólicos de folhas secas e frutos maduros de Melia azedarach (Meliaceae) sobre Aedes albopictus. Latin American Journal of Pharmacy 26 (5): 737-740.

SANTA CATARINA. 2012. Secretaria de Estado da Saúde. Diretoria de Vigilância Epidemiológica. Informações Dengue. [Internet] 
[cited 2015 nov 11]. Available at: http://www.dive.sc.gov.br/ conteudos/zoonoses/Vetores/dengue/A_Dengue_no_Brasil_e_ SC 2012.pdf. [Review date: 01 September 2015].

SCAPIN̄ELLO, J.; OLIVEIRA, J. V.; CHIARADIA, L. A.; TOMAZELLI, J. R. O.; RIBEIROS, M. L.; DAL MAGRO, J. 2014a. Effects of supercritical $\mathrm{CO}_{2}$ extracts of Melia azedarach L. on the control of fall armyworm (Spodoptera frugiperda). The Journal of Supercritical Fluids 93: 20-26.

SCAPINELLO, J.; OLIVEIRA, J. V.; CHIARADIA, L. A.; TOMAZELLI, J. R. O.; RIBEIROS, M. L.; DAL MAGRO, J. 2014b. Insecticidal and growth inhibiting action of the supercritical extracts of Melia azedarach on Spodoptera frugiperda. Revista Brasileira de Engenharia Agrícola e Ambiental 18 (8): 866-872.

SIMAS, N. K.; LIMA, E. C.; CONCEIÇÃO, S. R.; KUSTER, R. M.; OLIVEIRA FILHO, A. M. 2004. Produtos naturais para o controle da transmissão da dengue - Atividade larvicida de Myroxylon balsamum (Óleo vermelho) e de terpenóides e fenilpropanóides. Química Nova 27 (1): 46-49.

SOARES-DA-SILVA, J.; PINHEIRO, V. C. S; LITAIFF-ABREU, E.; POLANCZYK, R. A.; TADEI, W. P. 2015. Isolation of Bacillus thuringiensis from the state of Amazonas, in Brazil, and screening against Aedes aegypti (Diptera, Culicidae). Revista Brasileira de Entomologia 59 (1): 1-6.

TAUIL, P. L. 2001. Urbanização e ecologia da dengue. Cadernos de Saúde Pública 17: 99-102.

VALLADARES, G.; DEFAGO, M. T.; PALACIOS, S. 1997. Laboratory evaluation of Melia azedarach (Meliaceae) extracts against the elm leaf beetle (Coleoptera: Chrysomelidae). Journal of Economic Entomology 90 (3): 747-750.
WORLD HEALTH ORGANIZATION (WHO). 1999. Microbial pest control agent, Bacillus thuringiensis. Geneva, World Health Organization. Environmental Health Criteria 217.

WORLD HEALTH ORGANIZATION (WHO). 2004. Report of the seventh whopes working group meeting. [cited 2017 nov 11]. Available from: http://apps.who.int/iris/ bitstream/10665/68541/1/WHO_CDS_WHOPES_2004.8.pdf. [Review date: 10 October 2016].

WORLD HEALTH ORGANIZATION (WHO). 2007. Pyriproxyfen in drinking-water background document for development of WHO. Guidelines for drinking-water quality, WHO/SDE/ WSH/07.01/10, 1-13, WHO Press.

YUNES, R. A.; CALIXTO, J. B. 2001. Plantas medicinais sob a ótica da química medicinal moderna. Chapecó: Argos, 523 p.

ZARA, A. L. S. A.; SANTOS, S. M. D.; FERNANDES-OLIVEIRA, E. S.; CARVALHO, R. G.; COELHO, G. E. 2016. Estratégias de controle do Aedes aegypti: uma revisão. Epidemiologia e Serviços de Saúde, Brasília 25 (2): 391-304.

Received: 20-Nov-2016 • Accepted: 12-Sep-2017

Suggested citation:

BUSATO, M. A.; LUTINSKI, J. A.; HERMES, D.; MAGRO, J. D.; BORDIGNON, C. M.; BOHN, A.; SIMÕES, D. A. 2018. Larvicidal effects of supercritical extract of Melia azedarach and Bacillus thuringiensis var. israelensis product on late instar of Aedes aegypti (Diptera: Culicidae). Revista Colombiana de Entomología 44 (1): 39-43. Enero - Junio 2018. 